(2) Open Access Full Text Article

ORIGINAL RESEARCH

\title{
An empirical investigation on the relationship
} between a high-performance work system and employee performance: measuring a mediation model through partial least squares-structural equation modeling

This article was published in the following Dove Press journal: Psychology Research and Behavior Management

\section{Cai Li}

Shumaila Naz

Muhammad Aamir Shafique

Khan

Basil Kusi

Majid Murad

School of Management, Jiangsu University, Zhenjiang, Jiangsu 212013, People's

Republic of China
Correspondence: Shumaila Naz School of Management, Jiangsu University, 30 I Xuefu Road, Zhenjiang, Jiangsu 2I20I3, People's Republic of China Tel +86 I865286 620I

Email shumaila.superior@gmail.com
Background: This study aimed to investigate the effect of a high-performance work system (HPWS) on employee performance and the intervening role of mediators in this relationship. Methods: The study was quantitative in nature and used a questionnaire as its instrument. Two hundred and fifty respondents from the private textile sector, located in Lahore and Faisalabad, Pakistan, were selected using a stratified sampling technique. For statistical analysis and to test the proposed research model, partial least squares-structural equation modeling was applied.

Results: HPWS was positively related to employee performance. Furthermore, job satisfaction, perceived organizational support, and employee engagement positively and significantly mediated between HPWS and employee performance. Thus, the study provided evidence for the underpinning models of social exchange theory, and ability, motivation, and opportunity framework.

Conclusion: The study emphasizes that practitioners should develop strategies that could foster positive work attitudes and increase perceived organizational support to achieve higher levels of performance. It further describes some limitations and gaps for future research.

Keywords: high-performance work system, employee performance, job satisfaction, perceived organizational support, employee engagement

\section{Introduction}

A high-performance work system (HPWS) can make a dramatic contribution to the attainment of organizational goals, effectiveness, and success. ${ }^{1}$ The relationship between HPWS and performance has been widely elucidated in the domain of human resources management (HRM). ${ }^{2}$ HPWS is comprised of interrelated human resources (HR) activities, such as staffing, performance management, and retention of intellectual capital. ${ }^{3}$ HPWS can have a significant impact on organizational performance through employees' performance. ${ }^{4}$ However, less attention has been paid to exploring the role of HPWS and the ways in which it can determine employee performance. ${ }^{5}$ A thorough review of the literature revealed that many scholars have advocated empirical investigation on the outcomes of $\mathrm{HPWS}^{4,6,7}$ and, predominantly, the underlying mechanisms through which HPWS affects individual and work- 
related outcomes, ${ }^{5,8-11}$ such as employee performance. Although the relationship between HPWS and performance has attracted the attention of academia and researchers and has been widely discussed in the literature, ${ }^{1,12}$ the existing work still reveals some uncertainties in the relationship, possibly because key elements that contribute widely to the existence of such a relationship have yet to be determined. ${ }^{13}$ Despite spending extensive time analyzing HR bundles, researchers have failed to provide solid and confirmed answers to several fundamental questions related to the interrelationships between HPWS and performance.14 So, further research is necessary owing to prevalent confusion $^{15,16}$ and to reveal the mediating variables in this relationship. $^{13,14}$

A series of work in the domain of HPWS and performance relationships has emphasized the necessity to find out how and why HPWS affects employee job attitudes and behavior, instead of explicitly supporting the direct relationship. ${ }^{9,17-19}$ In accordance with social exchange theory (SET), HRM practices that are perceived by employees as supportive to them will be reciprocated with positive attitudes and behavior ${ }^{20}$ such as good performance. As already mentioned, little is known regarding the mechanisms through which HRM systems impact employee attitudes and behavior. ${ }^{18,21}$ Therefore, building on the work of "singling", perceived by employees from HR practices, ${ }^{22}$ and the organizational support perspective, ${ }^{23,24}$ perceived organizational support (POS) has been taken as a mediator between HPWS and employee performance.

According to Alfes et al, ${ }^{25,26}$ employee engagement may be helpful in providing the answer to how an effective HRM system can increase employee and organizational performance. Nevertheless, the theoretical and practical associations between HRM systems and employee engagement, ${ }^{27}$ and between engagement and performance, are not well formulated..$^{28-30}$ To date, less is known about how HRM systems affect individualrelated outcomes through employee engagement, ${ }^{25,28}$ especially in the context of the Pakistani textile industry. Therefore, this study takes employee engagement as the mediator between the HPWS-employee performance link. Provided that employee engagement is primarily a motivational variable, further inclusion of the engagement and HR practices with the support of ability, motivation, and opportunity (AMO) models is evidently warranted. Besides this, the present study responds to the call of studies $^{3,31}$ that emphasize that the impact of HPWS, particularly on employees from a similar area rather than a diverse group, should be discussed. Therefore, employees at a manufacturing work site in Pakistan have been taken as respondents; this is a group that has not been empirically studied to date, with an understudied research model. The Pakistani textile industry contributes approximately $46 \%$ to the total output or $8.5 \%$ of the country's gross domestic product (GDP). Within Asia, Pakistan is the eighth largest exporter of textile products and provides employment to $38 \%$ of the workforce in the country. Yet, the industry is facing challenging issues of product quality, technology, and innovation. Therefore, it is necessary to find ways that could improve functional outcomes via employee performance.

This study fills the aforementioned research gaps, and therefore contributes to current theory on the HPWS-performance relationship, in three ways. First, it assumes that HPWS and job attitudes are important predecessors of employee performance. HPWS provides an efficient structure that directs toward higher organizational performance, yet few studies have explained its effect on employee performance. Second, while responding to the call for further studies, the current study identifies the possible mediators, such as job satisfaction, engagement, and POS, that may help in understanding the "black boxes". It refers to the interplay of some untapped mediators, such as job attitudes (job satisfaction, organizational commitment, and employee engagement), ${ }^{32,33}$ in the relationship between HRM and performance. Third, the study broadens the understanding of the link between HPWS and performance, and offers sufficient empirical evidence for AMO frameworks and SET.

The studied constructs have been defined in a variety of ways in the literature. For instance, HPWS refers to individual, interrelated, coherent HRM practices, which are formulated to improve both employee and firm performance while promoting people's competence, work attitudes, and motivation. ${ }^{34,35}$ Job satisfaction is defined as an employee's positive evaluation or assessment of their job content and context, resulting in a positive emotional state. ${ }^{36,37}$ POS is defined as how employees perceive that their organization takes notice of their input and pays significant attention to their well-being. ${ }^{23,38}$ Employee performance refers to activities stated by the employer and demanded from the employee through the job description; such actions are mandatory, evaluated, and compensated for by the employer. Employee engagement reflects employees' emotional and intellectual involvement with their employing organization. ${ }^{39}$ 
Hence, the main purpose of this study is to fill the current gap by exploring the interrelationship between HPWS and performance in detail and to find answers to untapped queries. By doing so, this study responds to the call of previous research, ${ }^{16,40}$ which call for the inclusion of mediating variables in the aforementioned relationship to accept or reject the existence of such a relationship. This requires scholars either to admit that HR practices bundle impacts on performance or to investigate the interplay of different constructs between this relationship. ${ }^{41}$ Another purpose of the research is to emphasize the contribution of modern work systems such as HPWS in the textile industry in Pakistan. The textile industry in Pakistan could grow more rapidly if factories would apply the true essence of HPWS. Manufacturing factories in Pakistan are influenced by "Sethi culture", in which powers are held only by owners but managers are not empowered to make decisions. Subsequently, manufacturing organizations lack innovation, technological growth, and excellence in performance. Therefore, the current study presents HPWS as a driver of power-sharing with all levels of management to increase employee performance. In particular, line managers can play an active role in enforcing HPWS after obtaining information from the HR department. ${ }^{42}$

The following section delivers a literature review on the studied variables of the current article; then the research model is presented, with hypotheses to be tested. The next section comprises results and findings, and the article concludes with a discussion.

\section{Literature review \\ HPWS and employee performance}

HPWS comprises a multitude of both control- and commitment-based HR practices. ${ }^{34,43}$ According to Evans and Davis, ${ }^{44}$ HPWS consists of internally congruent HR practices (horizontal alignment) and objectives that are externally congruent with the organization (vertical alignment). HPWS is comprised of set HR practices, including recruitment and selection, training and development, performance management, salary and benefits, loosely defined job duties, and involvement in decision making. ${ }^{45-49}$ Benefits of HPWS are generally seen as providing ample chances for involvement in decision making, skills enrichment, and career expansion. Previous studies have either examined the impact of individual HRM practices or measured bundles of HRM practices. Both perspectives provide evidence for the predictable relationship between HPWS and individual or organizational performance..$^{50,51}$ Indeed, HPWS encourages and integrates an individual's work attitudes and behaviors ${ }^{11}$ with the strategic goals of the organization which, in turn, enhances employee performance. Hence, HPWS is a configuration of HRM practices intended to improve employees' attitudes and subsequently their performance. ${ }^{38,52}$

The advent of strategic HRM shifted the attention of researchers from control-oriented HR practices to commitment- and performance-based HR practice bundles. ${ }^{53}$ Many strategic HR studies have been performed to investigate the relationship between HPWS and performance, and the influence of this relationship on organizational sustainability. ${ }^{54}$ Studies in a similar vein have measured the constructs of productivity, employee intentions to leave, employee performance, organizational citizenship behavior, organizational commitment, etc, with the HPWS. $^{55}$

HPWS is deployed so that organizational activities can be performed in a productive manner. ${ }^{7,56}$ Integration of HR practices has a combined effect on desirable workrelated outcomes, ${ }^{16,57} \mathrm{eg}$, greater innovation, ${ }^{58}$ increased organizational performance, ${ }^{4}$, and sustained competitive advantage. ${ }^{59}$ HPWS is adopted by organizations to improve employee performance. ${ }^{60}$ HPWS and performance outcomes are significantly associated with each other. ${ }^{4,60,61}$ Thus, the following hypothesis is postulated:

H1. HPWS positively influences employee performance.

\section{HPWS and POS}

POS refers to the exchange between two parties, particularly employees and organizations. HPWS encompasses various employee-oriented activities that indicate to employees that their contributions are acknowledged and considered important for organizational success. Consequently, individuals feel higher levels of POS and are susceptible to social exchange relationships. ${ }^{17,45}$ Employees view HR practices as supportive, promising, and caring for their well-being. ${ }^{47,62}$

How the HPWS affects POS can be explained by discussing the individual effects of the HR practices included in this bundle. HPWS is made up of factors that can have a positive impact on employees' POS to a large extent. For instance, job security endorses employees' perception that the organization values their services and is 
making efforts towards employee retention, ${ }^{20}$ in turn, expanding the level of POS. The inclusion of training in HPWS implies that the organization is investing in employees' development, which fosters a higher level of POS. ${ }^{63}$ If employees are involved in decision making, then they ascribe this with a positive perception of justice ${ }^{37,38}$ and the sense that the organization notices their efforts. ${ }^{45}$ Another component of HPWS is knowledge sharing, which creates feelings of trust in and support from organization. $^{64}$ Communication regarding performance feedback, compensation, and perceived justice ${ }^{35}$ leads to employees having faith that the organization gives importance to their role. ${ }^{65}$ High-quality work, a construct of HPWS,20 also gives employees the notion that they are considered valuable. ${ }^{66}$ Based on the above literature, the following hypothesis is proposed:

H2. HPWS positively influences POS.

\section{POS and employee performance}

POS is explicitly connected to employees' work-related attitudes and behaviors to investigate the relationship between employees and their working environment. ${ }^{18,67,68}$ POS has been associated with job-related outcomes, eg, taking charge ${ }^{69}$ and improved performance, ${ }^{23}$ although a few studies have found the opposite, that POS is not linked to employee performance. ${ }^{70}$ Nevertheless, it is confirmed that POS is a socio-emotional resource. ${ }^{71}$ Socio-emotional needs, such as care and appreciation, are positively related to POS. ${ }^{23}$ In this vein, advocates of SET claim that when socio-emotional needs are fulfilled, this leads to the law of reciprocity $^{65,72}$ and violation of this law brings distress and anxiety. $^{73}$ Employees in a socio-emotional support exchange demonstrate more hard work and involvement to avoid embarrassment. $^{65,72}$ In the workplace, employees with socio-emotional needs feel obligated to recompense the fair treatment received from the employer. ${ }^{70}$ The link between POS and employee performance is underpinned by the SET, ${ }^{74}$ as it suggests that when employees perceive that they are supported by the organization they feel obliged to involve themselves in those actions that facilitate in the achievement of organizational goals. ${ }^{75,76}$ Kurtessis et al $^{76}$ claim that POS can instigate the law of reciprocity. Favors received from an organization create a desire to reciprocate the exchange relationship by meeting organizational standards as well as the expectation to increase performance, while believing that one's efforts will be observed and compensated accordingly. The earlier mentioned scholars, ${ }^{18,69}$ also conducted an empirical examination and found that there is a direct causal relationship between POS and performance. These verdicts are also validated and confirmed by the conservation of resources (COR) theory, which implies that POS may be considered as a stimulating resource that enhances an individual's motivation to perform at a greater level. Thus, on the basis of norms of reciprocity and the COR theory, it can be postulated that POS influences employee performance:

H3. POS positively influences employee performance.

\section{Mediating role of POS in the relationship between HPWS and employee performance}

Although a number of studies are available on strategic HRM, POS has not been investigated extensively as a mediator between HPWS and employee-related outcomes, ${ }^{45,46,48}$ such as employee performance. POS acts as a crucial element in engaging the two parties (employees and employer) in the social exchange relationship. $^{24,77}$

Earlier studies have established that HR practices which are part of HPWS send a message to employees that they are valued and expected to serve productively. ${ }^{22,78}$ Understanding on the part of employees that their organization is investing in their well-being drives them to support the organization by exerting extra effort in achieving set goals and balancing the exchange relationship79 Thus, to reciprocate the exchange relationship, employees experiencing HPWS positively are more motivated to show increased performance. ${ }^{46}$ These thoughts are grounded in organizational support theory (OST), which states that a firm's supportive environment and equitable compensation make people perceive that they are considered important, which in turn intensifies POS. ${ }^{70}$ As a result, employees with a strong level of POS leave no stone unturned to help the organization to achieve higher levels of performance.

Hence, the following hypothesis is proposed:

H4. POS mediates the positive relationship between HPWS and performance.

\section{HPWS and job satisfaction}

Job satisfaction is an affective component influencing one's cognitions about multiple facets of the job. ${ }^{80-83}$ Job satisfaction reflects an employee's emotional connection with his or her job and with various aspects of the job. 
HPWS significantly influences individuals' satisfaction with their jobs. A study on call center employees confirmed that HPWS is positively related with job satisfaction. Similarly, Vanden Berghe ${ }^{84}$ found that employees who encounter HPWS are more satisfied with their jobs if HPWS provides an opportunity to maintain a healthy relationship with their supervisor and supports them in maintaining their work-life balance. Similarly, according to $\mathrm{Wu}$ and Chaturvedi, ${ }^{85}$ HPWS has positive effects on employees' job satisfaction. In addition, Gould-Williams ${ }^{86}$ found that training (a component of HPWS) is significantly and positively related to employee involvement and job satisfaction.

HPWS is a precursor to employees' positive attitudes and behavior. HPWS is a combination of such functions (in particular, training and performance management) that assist employees in developing their skill, knowledge, and abilities, and transferring their learning in the workplace. ${ }^{87,88}$ This learning helps employees to exhibit functional behaviors, eg, higher job satisfaction, greater commitment, lower intentions to leave, and improved productivity, ${ }^{89}$ and subsequently, to obtain organizational accomplishments. ${ }^{87,88}$ Thereby, it is logical to assume the link between HPWS and job satisfaction because organizations can establish a conducive and satisfactory work environment through HRM practices. A satisfactory work environment, in turn, will foster feelings of love, care, and respect by their employers, and will be reciprocated by positive employee attitudes and behaviors at work, such as job satisfaction. Hence, HRM practices are applied organizationwide to foster improvement in several features of organizational performance, such as job satisfaction.

Based on the above rationale, it is anticipated that:

H5. HPWS positively influences job satisfaction.

\section{Job satisfaction and employee performance}

A positive appraisal of one's job fosters the desire to become more productive, innovative, and committed, and to be a better performer. However, there are divergent and inconsistent views on the job relationship between satisfaction and employee performance. Vanden Berghe $^{84}$ has reported that job satisfaction and job performance are weakly correlated, and the cause and effect relationship is inconclusive. Another study has also showed that job performance and job satisfaction are modestly correlated. ${ }^{90}$ In contrast, a large number of scholarly works have found that job satisfaction exerts significant a positive impact on employee performance. A positive attitude from job satisfaction has a strong predictive power to determine work-related behavior and job productivity. Researchers indicate that job satisfaction has a positive influence on employee performance through organizational commitment. ${ }^{91}$ Another study has showed that job satisfaction is positively associated with job performance. ${ }^{92} \mathrm{~A}$ study on Sri Lankans also gave positive results. ${ }^{93}$

The causal relationship is therefore ambiguous and still undergoing inquiry. It remains debatable whether to accept that higher job satisfaction enhances performance, or whether high-performing people derive greater satisfaction from their jobs. ${ }^{94}$ Nonetheless, many researchers support the view that there is weak to modest correlation between job satisfaction and job performance, ${ }^{95,96}$ while others emphasize that job satisfaction and job performance are highly correlated. ${ }^{37,97}$ Hence, this article investigates the link between job satisfaction and job performance to add to the literature in the Pakistani manufacturing context:

H6. Job satisfaction positively influences employee performance.

\section{Mediating role of job satisfaction in the relationship between HPWS and employee performance}

HPWS is comprised of a set of HR practices including recruitment and selection, training and development, performance management, salary and benefits, loosely defined job duties, and involvement in decision making. ${ }^{45-49}$ These HR activities are formulated to improve employee and organizational performance through increasing employees' abilities, attitudes, and skills. ${ }^{34}$ Formal HRM practices stimulate employees' job attitudes such as job satisfaction, and subsequently their performance. ${ }^{38,52}$ This is widely supported by norms of reciprocity that imply that favors gained in the form of supportive behavior from the boss, fair rewards, and feedback on performance satisfy employees, and satisfaction obtained from the application of HRM practices will be reciprocated through the exertion of extra energy to perform more effectively.

It is interesting to know why and how HPWS creates the desire to perform better on the part of employees. The answer may lie in the fact that HPWS enhances employee performance via job satisfaction. According to Paauwe and Richardson, ${ }^{101} 17$ HR practices produce multiple sets of jobrelated outcomes at the individual level that can be classified as employee skills, attitude, and behavior. The first constitutes individual capabilities; the second refers to job satisfaction, organizational commitment, and motivation; and the third 
includes availability and retention. It has been stated previously that these job-related outcomes may play a significant role as mediators in the relationship between HPWS and performance. ${ }^{33,99}$ Therefore, the following hypothesis is proposed:

H7. Job satisfaction mediates the relationship between HPWS and employee performance.

\section{HPWS and employee engagement}

A plethora of views can be found in the literature to describe and test the phenomenon of employee engagement. ${ }^{100}$ Employee engagement has been cited as an outcome of HPWS. ${ }^{101,102}$ Employee engagement is delineated as the drive and competency of an employee to proficiently aid the organization in the attainment of its goals and objectives, when employees perceive their working environment as supporting them. ${ }^{103}$ According to Kahn, ${ }^{103}$ engagement refers to the emotional attachment that motivates employees to completely engross themselves in their duties, emotionally, physically, and mentally. Work engagement is characterized by rigorous efforts, participation, and consistent endeavors aimed at accomplishing desired work objectives. ${ }^{104,105} \mathrm{Teh}$ and Sun $^{106}$ stated that HPWS has a significant positive link with employee attitudes and levels of engagement. These attitudes are established by positive employee perceptions regarding organizational politics, remuneration systems, hierarchy, performance goals, and culture. Engagement is deeply embedded in the congruent bundle of HR systems.${ }^{29}$ Since HPWS is aimed at encouraging a supportive and facilitative working environment, it would not be wrong to assume that HPWS is a predecessor of employee engagement. The study takes its basis from Alfes et al, ${ }^{25}$ who revealed that HR practices influence employee engagement positively. The current study proposes the following hypothesis:

H8. HPWS positively influences employee engagement.

\section{Engagement and employee performance}

Managing employee performance is crucial to create efficiency and productivity in an organizational system An effective performance management system is an important antecedent of employee performance which leads to improved organizational performance and success. ${ }^{107,108}$ Considering the importance of employee performance, it is necessary to identify factors enhancing performance.
Employee performance is the outcome of employee engagement. ${ }^{109,110}$

Engaged employees not only are inclined to perform job duties but also attach their intellect, feelings, and emotions to their work. ${ }^{111}$ Engaged employees make collaborative efforts with group members, feel obligated to perform, and are powered by the desire to achieve set targets. ${ }^{112,113}$ Engaged employees focus more fully to perform their work than disengaged employees. ${ }^{110}$ Previous research has claimed that engagement influences employee performance. ${ }^{110,114,115}$ People who are engaged with their work express functional behaviors, which lead to the development of a team that works collectively towards mutual objectives and goals. ${ }^{116,117}$ Teamwork brings synergy which, in turn, increases employee performance. ${ }^{118}$ Engaged employees continually expend energy and are capable of sharing their emotions with other members of the organization. ${ }^{118}$ If people work as a team then their output will increase owing to synergic effects. ${ }^{119}$ Therefore, it is hypothesized that:

H9. Employee engagement positively influences employee performance.

\section{Mediating role of engagement in the relationship between HPWS and employee performance}

The HR practice's system and performance relationship indicates that HR practices are aimed at developing, motivating, maintaining, and retaining workforce productivity, innovation, and organizational citizenship behavior which, in turn, enhance performance and development. ${ }^{89}$ In the same way, ${ }^{14}$ the HRM and performance model highlights how employees work hard, display positive behavior, and participate in decision making because HPWS and these supportive attitudes and behaviors motivate higher individual and organizational performance. It has also been suggested that employee engagement may provide the key to unlock the black box of HR systems and performance linkage. ${ }^{25}$ In the context of first line employees and their managers employed in Romanian hotels, work engagement played a considerable role as the mediator in the relationship between HPWS and job performance. ${ }^{120}$ This suggestion is congruent with the theoretical idea that HPWS delivers favors to employees by providing organizational resources such as a conducive environment in which to learn the organization of tasks, impart skills, and provide induction and integration with other staff. The availability of such resources can make employees 
happy and enable them to demonstrate more positive attitude towards their job which, in turn, brings feelings of eagerness to the job to achieve the desired goals through employee engagement.

Surprisingly, less research has been performed to empirically test the relationship between HRM practices and employee engagement, and the relationship between employee engagement and individual performance; therefore, such relationships are not well articulated, ${ }^{28-30}$ especially in the context of employees working in the textile industry in Pakistan. Less is known about the impact of HR systems on individual- and work-related outcomes via the mechanism of employee engagement. ${ }^{25,28}$ This led us to investigate the interplay among these constructs. In summary, earlier studies have found significant and positive relationships between HPWS and employee engagement, ${ }^{106}$ with engagement influencing employee performance ${ }^{110}$ and employee engagement mediating the relationship between HPWS and employee performance. ${ }^{120}$ So, it is formulated that:

H10. Employee engagement mediates the relationship between HPWS and employee performance.

\section{Research framework}

This study is underpinned by two theoretical perspectives, namely the AMO model and SET. The conceptual model of the study is shown in Figure 1, which demonstrates all the hypotheses.

\section{The AMO framework}

Three stimuli, namely abilities, motivation, and opportunities, are the main components of the AMO model. Previously, the AMO model has been widely connected with the HRM-performance relationship. There is $\mathrm{S}$ dichotomy between HR practices and the AMO framework. On one side, it is clear that HPWS can enhance an individual's skill, ability, and motivation, ${ }^{88}$ and on the other side, the AMO theory builds the context for HR practices to provide desirable outcomes. ${ }^{121}$ The three drivers of abilities, motivation, and opportunities set the background to how HPWS can improve employee performance. Indeed, HPWS takes its input from AMO and contributes towards the financial growth of the organization, thus increasing organizational efficiency. For instance, when employees are given training, their knowledge, skills, and abilities are enhanced; therefore, they feel supported, motivated, and satisfied; and, thus, become engaged and perform at a higher level. In addition, when employees are compensated and treated fairly, they feel higher motivation and so increase their performance. These findings are consistent with those of Purcell and Kinnie, ${ }^{16}$ who contend that improved job attitude, performance, and work behavior are the outcomes when AMO criteria are met. The present study provides evidence for the AMO theory by showing that HPWS is an antecedent of employees' positive attitudes and behavior, such as job satisfaction and engagement, and subsequently increases employee performance. This study is in line with studies that view the link between HRM and performance through the mechanism of employee attitudes. ${ }^{11,122}$ Based on this, the current study postulates that HR practitioners can establish conducive opportunities for employees to utilize their knowledge, skills, and abilities, which, in turn, results in positive work attitudes such as job satisfaction and employee engagement, and ultimately higher employee performance. $^{3,123,124}$

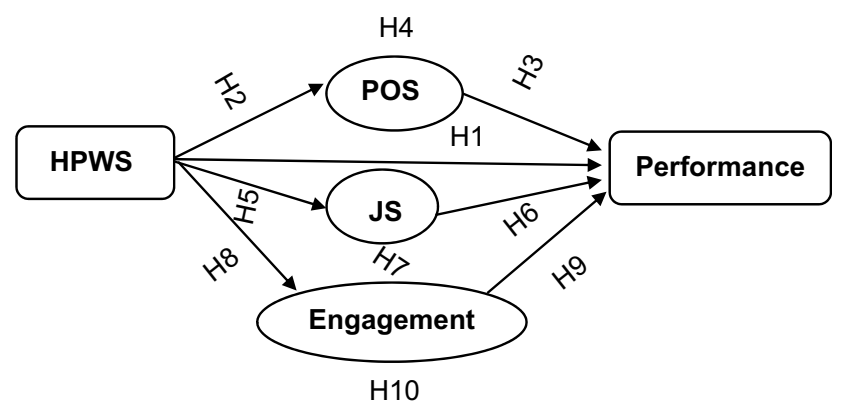

Figure I Model Confirmatory factor analysis.

Abbreviations: EE, employee engagement; EP, employee performance; HPWS, high-performance work system; JS, job satisfaction; POS, perceived organizational support; PS. 


\section{SET}

SET is a pioneering perspective that has been extensively applied to social relationships within organizations. ${ }^{125}$ This theory is based on the hypothesis that employees indulge in social exchange relationships with their organization when they feel that favors are received from their employer firm. ${ }^{126}$ Such exchange relationships endorse some obligations to behave in a similar way. When textile firms offer benefits of participation in decision making, equitable rewards, feedback, fair treatment, supportive supervisor behavior, etc, through the implementation of HPWS, employees would feel obligated to improve their performance. To elucidate the influence of HPWS on employee performance, the present research is predominantly extracted from SET to explicate the underlying mechanism in the scant literature on HPWS. ${ }^{51}$ Thus, SET encompasses an indeterminate obligation on employees to reciprocate the support received from the employer to gain equilibrium in the relationship. HPWS sends a message to employees that their socio-emotional needs are accommodated by providing job security, empowerment, and training. If employees perceive that HPWS is characterized by supportive HR practices, then, in return, they exercise positive behavior and attitudes that are encouraged by the organization, such as job performance, job satisfaction, job engagement, job commitment, reduced turnover, less absenteeism, and subsequently organizational efficiency, to balance the exchange relationship. ${ }^{21}$ This is the key attribute of SET: that favors obtained owing to HPWS act as stimuli for employees to perform better by exhibiting work engagement and satisfaction regarding aspects of the job. This leads us to conclude that POS, job satisfaction, and employee engagement, which stem from HR practices, are inclined to result in increased performance. ${ }^{115,127,128}$

Line managers can make a great contribution in applying SET because they are increasingly considered as the agents in organizations to enforce formal HR practices in the workforce, ${ }^{42}$ since they undertake more HR-related responsibilities, such as staff recruitment, training, feedback, and appraisal. Application of an objective HR system can guarantee higher employee motivation.

\section{Methodology}

The prime objective of this study was to determine the factors influencing employee performance. It attempted to find the intervening mediating variables in the relationship between HPWS and employee performance. The research was performed in the textile sector of Pakistan because this sector has made significant contributions towards raising GDP, employment, exports, and the economy. Furthermore, there is a lack of awareness about the importance of the application of HPWS owing to the Sethi culture in the textile sector in Pakistan. The study used a positivism paradigm under a deductive approach. Positivism is based on the singular reality of knowledge under ontological assumptions. Quantitative methodology is widely used when the researcher wants to address the empirical nature of a question. So, in line with the research questions and hypotheses, this study employed a positivist paradigm while acknowledging interpretivist and pragmatist paradigms.

\section{Instrument development and questionnaire design}

Five variables were used in this study: HPWS, POS, job satisfaction, performance, and engagement. Since the studied variables had already been examined previously, and valid and reliable scales were available in the literature, scales for these variables were not designed, but rather adapted from various scholars, as shown in Table S1. To ensure the validity of the instrument in the context of Pakistani textile sector, a pilot study of 50 employees was conducted before the actual data collection. From their responses, minor changes were made in data survey questionnaire to make this study more valid and understanding of respondents. The minor changes (replacement of "administered" and "have been subject to a" with "hired" and "are designed after", respectively, omission of word "structured") were made in item numbers 1, 2, and 15 for the variable of HPWS.

\section{Sample and data collection}

Data were obtained through questionnaires administered to employees of three private textile companies (Sapphire, Us Denim, and Style textile) located in Lahore and Faisalabad. The participants were selected using a non-probability stratified sampling technique by dividing the target population into four strata. The formula for calculating sample size ${ }^{129}$ is: $Z^{2} * p(1-p) / e^{2}$, where $z=1.6384, p=0.25$, and $e^{2}=0.0016$. According to this formula, the sample size for this study is approximately 350 . Therefore, 400 questionnaires were distributed to the employees. The respondents belonged to different age groups, educational levels, and experience 
levels, working in a variety of positions. Two avenues for data collection were used. First, questionnaires were sent by e-mail to the head of each department, asking them to forward the email to their employees. Second, a selfadministered survey was performed after obtaining formal permission via telephone to conduct the survey. In total, 250 questionnaires were returned, with a response rate of $62.5 \%$, of which 232 responses were used for further analysis after a data-screening process comprising three steps: reduction of unengaged responses, omission of outliers, and deletion of responses constituting missing values.

\section{Measures}

Scales to measure the studied variables were selected on the basis of their reliability and validity. HPWS was measured as an exogenous variable through 16 items adopted from $\mathrm{Fu}$ et al. ${ }^{43}$ However, items number 1, 3, and 10, namely PS1, PS3, and PS10, were deleted owing to lower factor loadings. A lower factor loading indicated that a particular item did not load on its relative latent variable. The items of HPWS comprised statements on staffing, training and development, coaching, involvement in decision making, knowledge sharing, rewards, and performance appraisal. Responses were gathered on their perception regarding the presence of these HR practices. A sample item is "Receive formal individual performance appraisals". Cronbach's alpha for HPWS was 0.718. Employee engagement was measured using the nineitem Utrecht Work and Engagement Scale adopted from Hakanen et al. ${ }^{130}$ One example is "At my work, I feel bursting with energy". Cronbach's alpha for employee engagement was 0.767. POS was measured using eight items adopted from a revised shortened version of the Survey of Perceived Organizational Support (SPOS) from Eisenberger et al. ${ }^{23}$ This scale was used owing to its increased application and acceptance in the social sciences. ${ }^{43,63}$ A sample item is "The organization appreciates any extra effort from me". Cronbach's alpha for POS was 0.779. Employee performance was measured using a five-item performance scale by Janssen and Van Yperen. ${ }^{131}$ The job performance scale was used in reference to the participants' self-reports. One of the items is "I am often able to perform essential duties". Cronbach's alpha for employee performance was 0.757. Job satisfaction was measured using a three-item job satisfaction questionnaire adopted from Cammann et al. An example item is "In general, I like my job". Cronbach's alpha for HPWS was 0.82. A Likert scale ranging from strongly disagree to strongly agree (1-5) was used to measure the responses for all constructs.

\section{Demographics}

The demographics of the respondents are as follows. With respect to gender, there were 208 males, accounting for $89.7 \%$, while females made up $10.3 \%$ of the target population. Regarding age group, five (2.2\%) were aged under 20 years, $119(51.3 \%)$ 20-30 years, $78(33.6 \%)$ 31-40 years, 28 (12.1\%) 41-50 years, and only two (0.9\%) were aged above 50 years. Only four (1.7\%) had an MPhil or PhD, $50(21.6 \%)$ had a master's degree, 90 (39.2\%) had a graduate degree, 70 (30.2\%) had an intermediate degree, and 17 (7.3\%) had matriculation or lower education. Respondents had different positions in the companies: $83(35.5 \%)$ were customer representative officers, 42 (18.1\%) were team coordinators, 45 (19.4\%) were team leaders, 18 (7.8\%) were assistant managers, 22 (9.5\%) were senior managers, and 21 (9.1\%) were heads of department. With respect to type of appointment, $185(79.7 \%)$ were permanent staff, $40(17.2 \%)$ were on a full-time contractual appointment, and seven (3\%) were appointed on a part-time contract. Data on experience showed that $32(13.8 \%)$ has less than 2 years' experience, $85(36.6 \%)$ had 2-5 years' experience, 55 (23.7\%) had 6-10 years' experience, 40 (17.2\%) had 11-15 years' experience, and $20(8.6 \%)$ had more than 15 years' experience.

\section{Statistical analysis and hypothesis testing}

To test the proposed model, partial least squares-structural equation modeling (PLS-SEM) was applied, since this has acted as a silver bullet in management research for estimating causal models in many theoretical models and empirical research. $^{132}$

\section{Measurement model Findings}

To test the measurement model, construct reliability and validity were checked. Table 1 demonstrates the factor loadings, composite reliability (CR), and average variance extract (AVE), used to check the convergent validity of constructs. The measurement scale has convergent validity if the factor loading of the items is greater than or equal to $0.50 .^{132}$ All the items were above the acceptable range except for three items of HPWS, two items of POS, and one item of engagement. Thus, these items were deleted since, as a rule of thumb, $20 \%$ of the total items can be deleted. Factor loadings of the retained items are shown in Figure 2. Convergent validity of the studied variables was also established through AVE and $\mathrm{CR}$ values. According to the established criteria, an AVE 
Table I Confirmatory factor analysis

\begin{tabular}{|c|c|c|c|c|c|}
\hline Construct & & $\begin{array}{l}\text { Factor } \\
\text { loading }\end{array}$ & Alpha & AVE & CR \\
\hline $\begin{array}{l}\text { Employee } \\
\text { engagement }\end{array}$ & $\begin{array}{l}\text { EEI } \\
\text { EE2 } \\
\text { EE3 } \\
\text { EE4 } \\
\text { EE5 } \\
\text { EE6 } \\
\text { EE7 } \\
\text { EE8 }\end{array}$ & $\begin{array}{l}0.639 \\
0.659 \\
0.722 \\
0.647 \\
0.656 \\
0.674 \\
0.666 \\
0.652\end{array}$ & 0.767 & 0.517 & 0.842 \\
\hline $\begin{array}{l}\text { Employee } \\
\text { performance }\end{array}$ & $\begin{array}{l}\text { EPI } \\
\text { EP2 } \\
\text { EP3 } \\
\text { EP4 } \\
\text { EP5 }\end{array}$ & $\begin{array}{l}0.805 \\
0.72 \\
0.778 \\
0.664 \\
0.59\end{array}$ & 0.757 & 0.512 & 0.838 \\
\hline Job satisfaction & $\begin{array}{l}J S I \\
\text { JS2 } \\
\text { JS3 }\end{array}$ & $\begin{array}{l}0.877 \\
0.885 \\
0.809\end{array}$ & 0.82 & 0.735 & 0.893 \\
\hline . & $\begin{array}{l}\text { POS1 } \\
\text { POS2 } \\
\text { POS3 } \\
\text { POS4 } \\
\text { POS5 } \\
\text { POS6 }\end{array}$ & $\begin{array}{l}0.674 \\
0.741 \\
0.768 \\
0.723 \\
0.664 \\
0.648\end{array}$ & 0.779 & 0.528 & 0.848 \\
\hline HPWS & $\begin{array}{l}\text { PS2 } \\
\text { PS4 } \\
\text { PS5 } \\
\text { PS6 } \\
\text { PS7 } \\
\text { PS8 } \\
\text { PS9 } \\
\text { PSII } \\
\text { PSI2 } \\
\text { PSI3 } \\
\text { PSI4 } \\
\text { PSI5 } \\
\text { PS16 }\end{array}$ & $\begin{array}{l}0.62 \\
0.589 \\
0.597 \\
0.563 \\
0.651 \\
0.698 \\
0.646 \\
0.617 \\
0.611 \\
0.585 \\
0.645 \\
0.593 \\
0.561\end{array}$ & 0.718 & 0.533 & 0.82 \\
\hline
\end{tabular}

Abbreviations: AVE, average variance extract; CR, composite reliability; HPWS, high-performance work system; POS, perceived organizational support.

of 0.50 or above is acceptable. The AVE value for all the variables was above 0.50 , and CR was above 0.8 , showing convergent validity.

\section{Discriminant validity}

The Fornell-Larcker criterion and examination of crossloadings have been the primary methods used for measuring discriminant validity. ${ }^{133}$ However, it was found that the Fornell-Larcker approach did not accurately assess the discriminant validity. Therefore, the study used a substitute method, the multitrait-multimethod matrix, to assess discriminant validity, ie, the heterotrait-monotrait ratio of correlations. ${ }^{133}$ Kline stated that the heterotrait-monotrait ratio should be less than 0.85 to ensure discriminant validity. As shown in Table 2, all the values are less than 0.85 . Hence, there is no issue of discriminant validity.

\section{Structural model}

\section{Structural equation modeling}

Hypotheses 1 and 2 predicted an effect of HPWS on employee performance and POS. The results in Table 3 and Figure 3 demonstrate a significant positive effect of emotional intelligence on employee performance $(\beta=0.256 ; t=3.82$; lower limit $[\mathrm{LL}]=0.192$, upper limit $[\mathrm{UL}]=0.072)$ and $\operatorname{POS}(\beta=0.469 ; t=8.944 ; \mathrm{LL}=0.371$, $\mathrm{UL}=0.574$ ), thus supporting $\mathrm{H} 1$ and $\mathrm{H} 2$. Moreover, the findings revealed that HPWS is significantly and positively related to job satisfaction $(\beta=0.44 ; t=7.339 ; \mathrm{LL}=0.326$, $\mathrm{UL}=0.553)$ and employee engagement $(\beta=0.273 ; t=3.899$; $\mathrm{LL}=0.144$, $\mathrm{UL}=0.413$ ), which support $\mathrm{H} 5$ and $\mathrm{H} 8$. Furthermore, the results signified that job satisfaction and employee performance are positively associated $(\beta=0.262$; $t=3.231$; $\mathrm{LL}=0.096$, $\mathrm{UL}=0.414$ ), and thus H6 is supported. Hypothesis 3, which proposed the relationship between POS and employee performance, is supported $(\beta=0.331$; $t=4.139$; $\mathrm{LL}=-0.062$, $\mathrm{UL}=-0.253)$. Furthermore, the results indicated that engagement is positively related to employee performance $(\beta=0.373 ; t=5.305 ; \mathrm{LL}=0.236$, $\mathrm{UL}=0.51$ ), thus supporting H9. $R^{2}$ denoted that HPWS explained $33.3 \%$ of the variation in employee performance, $22 \%$ of variation in POS, $19.3 \%$ of variation in job satisfaction, and $7.4 \%$ of variation in engagement. $F^{2}$ values reflected that HPWS had medium effects on job satisfaction and POS, but no effect on employee performance and only a small effect on engagement. POS had no effect on employee performance, whereas job satisfaction had a small effect on employee performance.

If $Q^{2}>0$, then there was no issue with blindfolding, and this has been used for measuring predictive relevance. ${ }^{134,135}$ Accordingly, Table 3 shows that all values of $Q^{2}$ were greater than zero. The variance inflation factor (VIF) refers to multicollinearity, and the findings demonstrated that HPWS, job satisfaction, POS, and engagement were not highly correlated with each other, as per the criterion that VIF values should be less than 5 .

As shown in Table 4, the findings revealed that engagement significantly mediates the relationship between HPWS and employee performance $(\beta=0.102 ; t=3.092 ; \mathrm{LL}=0.048$, $\mathrm{UL}=0.177$ ), thus supporting $\mathrm{H} 10$. Moreover, job satisfaction also significantly mediates the association between HPWS and 


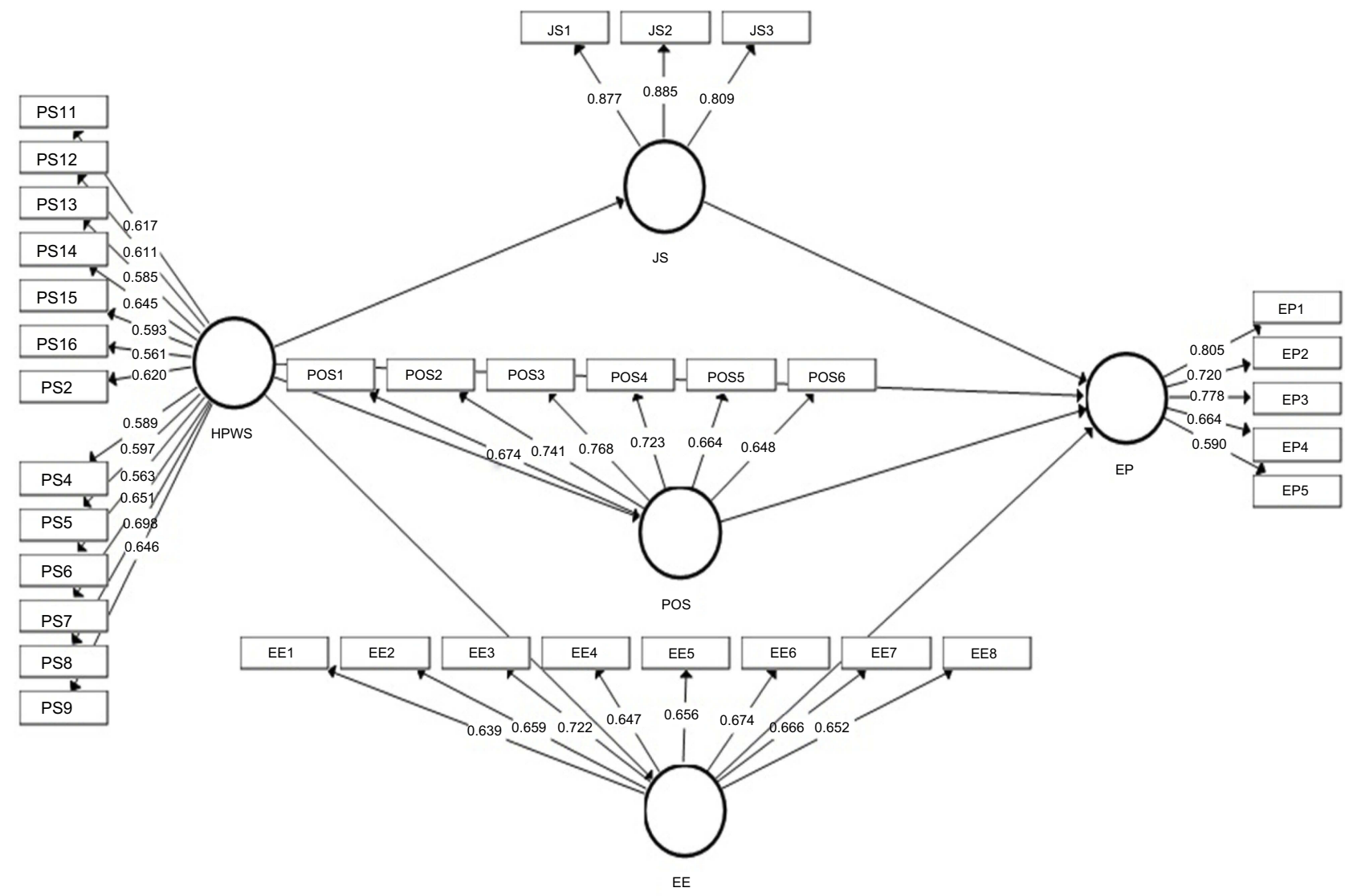

Figure 2 Confirmatory factor analysis. Abbreviations: EE, employee engagement; EP, employee performance; HPWS, high-performance work system; JS, job satisfaction; POS, perceived organizational support; PS,

Table 2 Discriminant validity

\begin{tabular}{|l|l|l|l|l|}
\hline & ENG & EP & HPWS & JS \\
\hline ENG & & & & \\
EP & 0.666 & & & \\
HPWS & 0.357 & 0.239 & & \\
JS & 0.595 & 0.561 & 0.534 & \\
POS & 0.508 & 0.424 & 0.597 & 0.537 \\
\hline
\end{tabular}

Abbreviations: ENG, engagement; EP, employee performance; HPWS, high-performance work system; JS, job satisfaction; POS, perceived organizational support.

employee performance $(\beta=0.115 ; \quad t=2.958 ; \quad \mathrm{LL}=0.039$, $\mathrm{UL}=0.199$ ), thus supporting H7. Similarly, POS also significantly mediates the association between HPWS and employee performance $(\beta=0.080 ; t=2.111 ; \mathrm{LL}=0.031, \mathrm{UL}=0.122)$, thus supporting $\mathrm{H} 4$.

\section{Discussion}

Although the association between HPWS and organizational performance has been widely studied, there has been limited investigation into the relationship between HPWS and employee performance. This study adds to the existing body of knowledge in the domain of HRM by empirically investigating the relationship between HPWS and employee performance and the mechanisms underlying this relationship. This research views HPWS and its attitudinal outcomes through the lens of workers in the manufacturing textile industry of Pakistan. H1 predicted a positive significant association between HPWS and employee performance. The prediction was supported by the findings of the current study. The results are consistent with earlier studies on similar constructs. $4,9,11,40,42,51,61,136$

The findings indicate that HPWS positively influences POS (H2). The benefits of HPWS are generally accredited to its providing ample chances for involvement in decision making, skills enrichment, and career expansion. $^{48,76}$ Employees perceive these benefits as advantageous and thereby act positively by increasing their efforts. This is demonstrated in this study by POS positively influencing performance (H3) and POS mediating the relationship between HPWS and employee 
Table 3 Path coefficients

\begin{tabular}{|c|c|c|c|c|c|c|c|c|c|c|c|c|}
\hline Hypothesis & Relationship & $\begin{array}{l}\text { Std } \\
\text { beta }\end{array}$ & $\begin{array}{l}\text { Std } \\
\text { error }\end{array}$ & $t$ & $P$ & LL & UL & Decision & $R^{2}$ & $f^{2}$ & $Q^{2}$ & VIF \\
\hline $\mathrm{HI}$ & HPWS $\rightarrow$ EP & 0.256 & 0.067 & 3.82 & 0 & 0.192 & 0.072 & Supported & 0.333 & 0.003 & 0.153 & 1.402 \\
\hline $\mathrm{H} 2$ & HPWS $\rightarrow$ POS & 0.469 & 0.052 & 8.944 & 0 & 0.371 & 0.574 & Supported & 0.22 & 0.281 & 0.102 & \\
\hline $\mathrm{H} 3$ & $\mathrm{POS} \rightarrow \mathrm{EP}$ & 0.331 & 0.08 & 4.139 & 0.002 & -0.062 & -0.253 & Supported & & 0.008 & & 1.474 \\
\hline H5 & $\mathrm{HPWS} \rightarrow \mathrm{JS}$ & 0.44 & 0.06 & 7.339 & 0 & 0.326 & 0.553 & Supported & 0.193 & 0.24 & 0.13 & \\
\hline $\mathrm{H} 6$ & $\mathrm{JS} \rightarrow \mathrm{EP}$ & 0.262 & 0.081 & 3.231 & 0.001 & 0.096 & 0.414 & Supported & & 0.066 & & 1.553 \\
\hline $\mathrm{H} 8$ & HPWS $\rightarrow$ ENG & 0.273 & 0.07 & 3.899 & 0 & 0.144 & 0.413 & Supported & 0.074 & 0.08 & 0.034 & \\
\hline $\mathrm{H} 9$ & $\mathrm{ENG} \rightarrow \mathrm{EP}$ & 0.373 & 0.07 & 5.305 & 0 & 0.236 & 0.51 & Supported & & 0.152 & & 1.363 \\
\hline
\end{tabular}

Abbreviations: ENG, engagement; EP, employee performance; HPWS, high-performance work system; JS, job satisfaction; POS, perceived organizational support; LL, lower limit; UL, upper limit; VIF, variance inflation factor.

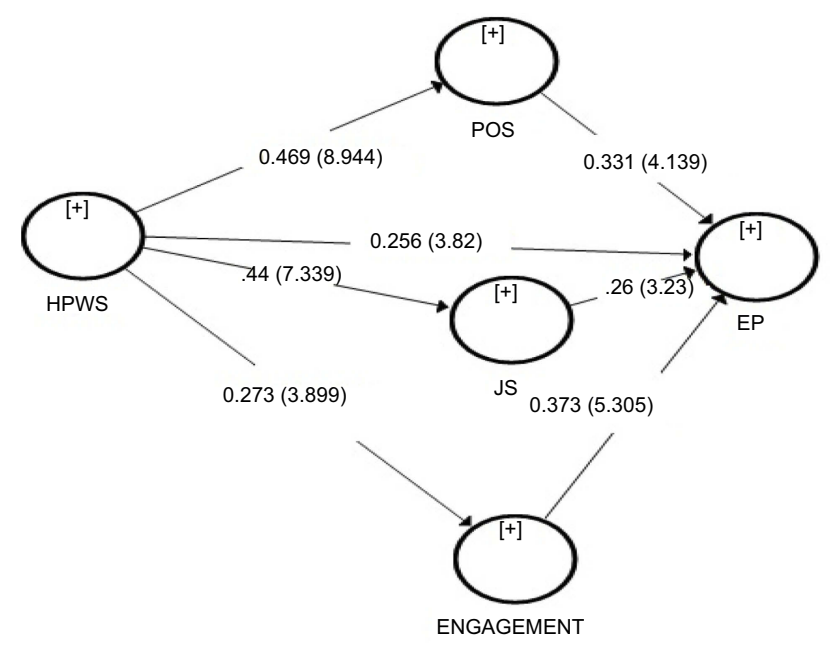

Figure 3 Structural modeling path modeling. Abbreviations: EP, employee performance; HPWS, high-performance work system; JS, job satisfaction; POS, perceived organizational support

performance (H4). This finding is supported by Liu et al. ${ }^{137,138}$ Studies have suggested that it is crucial to explore the mechanisms through which HRM systems influence employee attitudes and behavior. ${ }^{9,17-19}$ This research takes inspiration from the study of Shen et al, ${ }^{18}$ which insists that intervening mechanisms through which HR bundles exert effects on employee attitudes and behavior should be further explored. To gain in-depth insights into these relationships, evidence is provided from the textile sector in Pakistan.

The HPWS bundle includes HR practices that makes employees happy and satisfied (H5). This study is built on the limited literature on HPWS and job satisfaction. ${ }^{85,139}$ Satisfaction gained from HR practices sends a message of positive perceptions that their concerns are addressed and directs them to improve their performance. The results

Table 4 Indirect effects

\begin{tabular}{|l|l|l|l|l|l|l|l|l|}
\hline Hypothesis & Relationship & Std beta & Std error & $\boldsymbol{t}$ & $\boldsymbol{P}$ & LL & UL & Decision \\
\hline HIO & HPWS $\rightarrow$ ENG $\rightarrow$ EP & 0.102 & 0.033 & 3.092 & 0.002 & 0.048 & 0.177 & Supported \\
H7 & HPWS $\rightarrow$ JS $\rightarrow$ EP & 0.115 & 0.039 & 2.958 & 0.003 & 0.039 & 0.199 & Supported \\
H4 & HPWS $\rightarrow$ POS $\rightarrow$ EP & 0.080 & 0.038 & 2.111 & 0.267 & 0.031 & 0.122 & Supported \\
\hline
\end{tabular}

Abbreviations: ENG, engagement; EP, employee performance; HPWS, high-performance work system; JS, job satisfaction; POS, perceived organizational support; LL, lower limit; UL, upper limit. 
demonstrate that job satisfaction positively influences employee performance (H6), which is consistent with previous studies. $^{90-93}$ When employees are satisfied by the supportive resources (training, rewards, and performance feedback) provided by the organization, they reciprocate the exchange relationship by raising their performance. So, job satisfaction mediates the relationship between HPWS and employee performance (H7). These findings are consistent with previous research. ${ }^{17,21,33}$

The results support the view that HPWS positively influences engagement (H8), which, in turn, increases employee performance (H9). The research is in line with Albrecht et al, ${ }^{101,109}$ who claimed that engagement needs to be embedded throughout the professional career. Engagement mediates the relationship between HPWS and employee performance (H10). This finding is supported by Karatepe et $\mathrm{al}^{120}$ and Alfes et al. ${ }^{25,26} 120$ These results add to the scant literature on the mediating mechanism in the relationship between HPWS and employee performance. Thus, this provides evidence to the AMO framework, as its three drivers are antecedents of HR practices and encourage employees to be highly engaged with their job. It attempts to identify the underlying mechanism by testing the role of mediators in the HPWS-performance relationship. Furthermore, employee engagement and job satisfaction are the attitudinal outcomes of HPWS and, in turn, result in increased efforts to perform, thus providing practical evidence for the SET and AMO models by empirically testing research hypotheses.

\section{Implications}

The primary objective of this study was to measure the relationship between HPWS and employee performance, taking into consideration the intervening mechanisms of work attitudes (job satisfaction, POS, and engagement).

The study has many implications for HR professionals. First, the positive relationship between HPWS and job performance suggests that it may be beneficial for practitioners to adopt bundles of coherent HR practices (such as recruitment and selection, training and development, performance management, salary and benefits, loosely defined job duties, and involvement in decision making) to achieve higher performance. Second, the study suggests that practitioners ought to create environments that signal to employees that they are valued and are well taken care of by higher management. Exchange of favors with management would encourage employees to be more involved and to participate in organizational affairs. Third, a positive perception of HPWS is more necessary than its actual application. For instance, if employees are rewarded fairly but they do not believe that they are treated equally, then fair rewards will not result in increased performance. Employees are key assets, a unique and scarce resource, so organizations should try to improve their well-being by providing equitable rewards or fair treatment to induce feelings of fairness. Thus, it is very important that HR practitioners and professionals attempt to exert a positive psychological impact through adopting adequate HR strategies. Fourth, since the study empirically proves that work attitudes are important antecedents of performance, employers must focus on developing positive attitudes of satisfaction and engagement. Employers should avoid discouraging practices such as favoritism, poor rewards, and destructive performance feedback because these may lead to diminished positive perceptions about the organization. The study adds to the limited literature on work attitudes of job satisfaction and engagement by discussing the relationship between HPWS and performance.

\section{Limitations and future research}

This study, like other studies, is also prone to some limitations. These limitations can be used to explore future avenues for research. The first limitation is related to the treatment of variables. HPWS has been taken as a composite variable. Future research could measure the effects of HR practices separately and consider HPWS as a second order variable. The second limitation is concerned with the methodological design. Although this study relies on a theoretical perspective and earlier results, and adopts the modern technique of PLS-SEM for analytical purposes, application of a cross-sectional design limits the detection of causal relationships between HRM practices (or HPWS) and work attitudes and outcomes. This issue could be addressed by deploying a longitudinal design. Causality could be substantiated if longitudinal data were used to investigate the levels of POS, job satisfaction, engagement, and employee performance before and after the execution of HR practices (HPWS). The causal relationship between the perception of HPWS and job satisfaction can be a two-way process, as a positive perception of HR practices fosters a positive evaluation of one's job, and people with a positive evaluation are likely to perceive a higher level of HPWS. The third limitation is concerned with research constraints. 
It would be stimulating to extend the research model of this study to a variety of industries. This study has taken responses only from employees working in the textile industry, because of time and cost limitations. Despite these limitations, the present article provides opportunities for further research on the relationship between HPWS and job attitudes and outcomes.

\section{Conclusion}

This study contributes to the current literature on the HPWS-performance link and adds new knowledge on the mediating role of employee engagement, job satisfaction, and POS. It develops and validates a research model that describes employee performance and its antecedents in Pakistani textile establishments. The findings suggest that HR professionals in textile firms may find it advantageous to implement HR practices as a method of managing their workforce. In particular, HPWS practices as outlined in this study have been found to contribute positively towards job satisfaction, engagement, and performance of textile employees. This study can be helpful to the managing body of such manufacturing organizations to formulate strategies to develop an engaged and satisfied workforce, which is helpful in gaining a competitive advantage. Employees' satisfaction and engagement can be gained by giving people the opportunity to participate in decision making and communicating information through meetings, newsletters, memos, and emails. Organizations should always implement HR practices and mechanisms that could enhance employee performance and engagement. HR practices such as an effective performance appraisal system, development plans, an equitable reward system, a job design based on a job characteristics model, and an attractive salary and incentives, can enhance employee motivation, which, in turn, influences performance. Engaged employees could feel an intimate relationship with their employing organization and reciprocate the favors obtained through HPWS by improving their performance. The adoption of HPWS can produce positive job attitudes and outcomes in the form of improved engagement, satisfaction, POS, and performance. The findings have implications for the practice and theory of the HPWS and employee performance relationship, while providing evidence and confirming previous research on the positive relationship between HPWS and individual-related work outcomes, and also adding new knowledge on the mediating factors between HPWS and employee well-being.

\section{Ethics statement}

This study was carried out in accordance with the recommendations of the Ethical Principles of Psychologists and Code of Conduct of the American Psychological Association (APA). All participants gave consent in accordance with the Declaration of Helsinki. The review board of Jiangsu University exempted the research from ethical approval, as it was a survey-based study. The authors are affiliated to a Chinese institution although they are Pakistani by origin, and the study was conducted under the supervision of a Chinese professor. Human resources and administration managers in the textile sector gave consent over the telephone for conducting the questionnaire survey. Participants were identified through their supervisors and they filled in the questionnaires willingly.

\section{Acknowledgments}

This research was part of the Self-organized Cluster Entrepreneurship Behavior Reform, Evolution, and Promotion Strategies Study (no. 16BGL028), China National Social Science Foundation; Study on Bottleneck and Innovation of Postindustrial Intellectual Capital Development in Jiangsu Province (no. 14JD009), Jiangsu Province Social Science Foundation Project; and Interactive Effect Between Self-Organised Innovation and Industrial Cluster, Jiangsu Province Graduate Scientific Research Innovation Project (no. KYCX17-1746).

\section{Disclosure}

The authors report no conflicts of interest in this work.

\section{References}

1. Boxall P, MackyK. High-performance work systems and organisational performance: bridging theory and practice. Asia Pacific J Hum Resour. 2007;45(3):261-270. doi:10.1177/1038411107082273.

2. Subramony M. A meta-analytic investigation of the relationship between HRM bundles and firm performance. Hum Resour Manage. 2009;48(5):745-768. doi:10.1002/hrm.v48:5

3. Colakoglu S, Lepak DP, Hong Y. Measuring HRM effectiveness: considering multiple stakeholders in a global context. Hum Resour Manag Rev. 2006;16(2):209-218. doi:10.1016/j. hrmr.2006.03.003

4. Jiang K, Lepak DP, Han K, Hong Y, Kim A, Winkler AL. Clarifying the construct of human resource systems: relating human resource management to employee performance. Hum Resour Manag Rev. 2012;22(2):73-85. doi:10.1016/j.hrmr.2011.11.005

5. Harley B, Allen BC, Sargent LD. High performance work systems and employee experience of work in the service sector: the case of aged care. Br J Ind Relations. 2007;45(3):607-633. doi:10.1111/j.14678543.2007.00630.x

6. Ehrnrooth M, Björkman I. An integrative HRM process theorization: beyond signalling effects and mutual gains. J Manag Stud. 2012;49 (September):1109-1135. 
7. Takeuchi R, Chen G, Lepak DP. Through the looking glass of a social system: cross-level effects of high-performance work systems on employees' attitudes. Pers Psychol. 2009;62(1):1-29. doi:10.1111/j.1744-6570.2008.01127.x

8. Van De Voorde K, Beijer S. The role of employee HR attributions in the relationship between high-performance work systems and employee outcomes. Hum Resour Manag J. 2015;25(1):62-78. doi:10.1111/1748-8583.12062

9. Koser M, Rasool SF. High performance work system is the accelerator of the best fit and integrated hr-practices to achieve the goal of productivity : a case of textile sector. Glob Manag J Acad Corp Stud.2018;8(1):10-21.

10. Zhang B, Morris JL. High-performance work systems and organizational performance: testing the mediation role of employee outcomes using evidence from PR China. Int $J$ Hum Resour Manag. 2014;25(1):68-90. doi:10.1080/ 09585192.2013.781524

11. Zhang J, Akhtar MN, Bal PM, Zhang Y, Talat U. How do highperformance work systems affect individual outcomes: a multilevel perspective. Front Psychol. 2018;9:586. doi:10.3389/ fpsyg.2018.00586

12. Yasir M, Imran R, Irshad MK. Mediating role of organizational climate in the relationship between transformational leadership, its facets and organizational performance. Actual Probl Econ. 2013;145(7):559-569.

13. Danford A, Richardson M, Stewart P, Tailby S, Upchurch M. Partnership, high performance work systems and quality of working life. New Techol Work Employment. 2008;23.:151-166. doi: $10.1111 /$ j.1468-005X.2008.00210.x

14. Guest DE. Human resource management and performance: still searching for some answers. Hum Resour Manag J. 2011;21 (1):3-13. doi:10.1111/j.1748-8583.2010.00164.x

15. Dany F, Guedri Z, Hatt F. New insights into the link between HRM integration and organizational performance: the moderating role of influence distribution between HRM specialists and line managers. Int J Hum Resour Manag. 2008;19(11):2095-2112. doi:10.1080/ 09585190802404320

16. Purcell J, Kinnie N. HRM and business performance. In The Oxford Handbook of Human Resource Management. Oxford: Oxford University Press; 2009.

17. Wright P, Nishii L, Paauwe J, Guest D, Wright P. HRM \& Performance: Achievements \& Challenges. Hoboken: John Wiley \& Sons; 2013.

18. Shen M, Liu H, Kawahara D, Kurohashi S. Chinese morphological analysis with character-level POS tagging. Proc 52nd Annu Meet Assoc Comput Linguist (Short Pap). 2014;2:253258.

19. Ostroff C, Bowen DE. Reflections on the 2014-decade award: is there strength in the construct of HR system reflections on the 2014-decade award. Acad Manag Rev. 2015;41(2):196214.

20. Zacharatos A, Barling J, Iverson RD. High-performance work systems and occupational safety. $J$ Appl Psychol. 2005;90(1):7793. doi:10.1037/0021-9010.90.1.77

21. Korff J, Biemann T, Voelpel SC. Human resource management systems and work attitudes: the mediating role of future time perspective. J Organ Behav. 2017;38(1):45-67. doi:10.1002/job.2110

22. Ostroff $\mathrm{C}$, Bowen DE. Moving HR to a higher level: HR practices and organizational effectiveness. In: Klein KK, Kozlowski SW, editors. Multilevel theory, research, and methods in organizations. San Francisco: Jossey-Bass; 2000:211266.

23. Eisenberger R, Huntington R, Hutchison S, Sowa D. Perceived organizational support. J Appl Psychol. 1986;71(3):500-507. doi:10.1037/0021-9010.71.3.500
24. Eisenberger R, Stinglhamber F. Perceived organizational support. In: Perceived Organizational Support: Fostering Enthusiastic and Productive Employees. Washington DC: American Psychological Association; 2011:25-60.

25. Alfes K, Shantz AD, Truss C, Soane EC. The link between perceived human resource management practices, engagement and employee behaviour: A moderated mediation model. Int J Hum Resour Manag. 2013;24(2):330-351. doi:10.1080/ 09585192.2012.679950

26. Huang Y, Ma Z, Meng Y. High-performance work systems and employee engagement: empirical evidence from China. Asia Pacific J Hum Resour. 2018;56(3):341-359. doi:10.1111/17447941.12140

27. Mahdi SM, Liao J, Shaho HMN. The Impact of High Performance Work System (HPWS) on employee productivity as related to organizational identity and job engagement Shirzad. Eur J Bus Manag. 2014;6(39):1-25.

28. Sparrow P, Cooper C. Organizational effectiveness, people and performance: new challenges, new research agendas. J Organ Eff People Perform. 2014;1(1):2-13.

29. Guest D. Employee engagement: a sceptical analysis. J Organ Eff People Perform. 2014;1(2):141-156.

30. Albrecht S, Sparrow P, Balain S. Engaging HR Strategists: Do the Logics Match the Realities? Handbook of Employee Engagement. In: Perspectives, Issues, Research and Practice. Cheltenham: Edward Elgar; 2010:263-296. doi:10.4337/9781849806374.00033.

31. Boxall P. High-performance work systems: what, why, how and for whom? Asia Pacific J Hum Resour. 2012;50(2):169-186. doi:10.1111/j.1744-7941.2011.00012.x

32. De Oliveira LB, Da Silva FFRA. The effects of high performance work systems and leader-member exchange quality on employee engagement: evidence from a brazilian non-profit organization. Procedia Comput Sci. 2015;55.:1023-1030. doi:10.1016/j. procs.2015.07.092

33. Katou AA, Budhwar PS. Testing competing HRM-performance linkage models : evidence from the Greek manufacturing sector. Eur $J$ Int Manag. 2010;4(5):464-487. doi:10.1504/ EJIM.2010.034962

34. Huselid MA. The impact of human resource management practices on turnover, productivity, and corporate financial performance. Acad Manag J. 1995;38(3):635-672.

35. Aggarwal U, Datta S, Bhargava S. The relationship between human resource practices, psychological contract and employee engagement - implications for managing talent. IIMB Manag Rev. 2007;19(3):313-325.

36. Locke EA. The nature and causes of job satisfaction. In: Handbook of Industrial and Organizational Psychology. Wuhan: Scientific Research Publishing; 1976:1297-1349.

37. Cohen-Charash Y, Spector PE. The role of justice in organizations: A meta-analysis. Organ Behav Hum Decis Process. 2001;86 (2):278-321. doi:10.1006/obhd.2001.2958

38. Bowen DE, Ostroff C. Understanding HRM-firm performance linkages: the role of the "strength" of the HRM system. Acad Manag Rev. 2004;29(2):203-221.

39. Richman AL, Civian JT, Shannon LL, Jeffrey Hill E, Brennan RT. The relationship of perceived flexibility, supportive work-life policies, and use of formal flexible arrangements and occasional flexibility to employee engagement and expected retention. Community Work Fam. 2008;11(2):183-197. doi:10.1080/ 13668800802050350

40. Rasheed MA, Shahzad K, Conroy C, Nadeem S, Siddique MU. Exploring the role of employee voice between high-performance work system and organizational innovation in small and medium enterprises. J Small Bus Enterp Dev. 2017;24(4):670-688. doi:10.1108/JSBED-11-2016-0185 
41. Boxall PF, Purcell J. Strategy and Human Resource Management. London: Macmillan International Higher Education; 2011.

42. Pak J, Kim S. Team manager's implementation, high performance work systems intensity, and performance: a multilevel investigation. J Manage. 2018;44(7):2690-2715.

43. Fu N, Ma Q, Bosak J, Flood P. Exploring the relationships between HPWS, organizational ambidexterity and firm performance in Chinese professional service firms. $J$ Chinese Hum Resour Manag. 2015;6(1):52-70. doi:10.1108/JCHRM-09-2014-0029

44. Evans WR, Davis WD. High-performance work systems and organizational performance: the mediating role of internal social structure. J Manage. 2005;31(5):758-775.

45. Allen DG, Shore LM, Griffeth RW. The role of perceived organizational support and supportive human resource practices in the turnover process. J Manage. 2003;29(1):99-118.

46. Liao H, Toya K, Lepak DP, Hong Y. Do they see eye to eye? Management and employee perspectives of high-performance work systems and influence processes on service quality. $J \mathrm{Appl}$ Psychol. 2009;94(2):371-391. doi:10.1037/a0013504

47. Snape ED, Redman T. Industrial relations climate and union commitment: an evaluation of workplace-level effects. Ind Relat (Berkeley). 2012;51(1):11-28. doi:10.1111/j.1468-232X.2011. 00662.x

48. Wang Z, Zhang J, Thomas CL, Yu J, Spitzmueller C. Explaining benefits of employee proactive personality: the role of engagement, team proactivity composition and perceived organizational support. J Vocat Behav. 2017;101:90-103. doi:10.1016/j.jvb.2017.04.002

49. Takeuchi R, Lepak DP, Wang H, Takeuchi K. An empirical examination of the mechanisms mediating between high-performance work systems and the performance of Japanese organizations. $J$ Appl Psychol. 2007;92(4):1069-1083. doi:10.1037/00219010.92.4.1069

50. Raeder S, Knorr U, Hilb M. Human resource management practices and psychological contracts in Swiss firms: an employer perspective. Int J Hum Resour Manag. 2012;23(15):3178-3195. doi:10.1080/09585192.2011.637066

51. Kehoe RR, Collins CJ. Human resource management and unit performance in knowledge-intensive work. J Appl Psychol. 2017;102(8):1222-1236. doi:10.1037/ap10000216

52. Becker BE, Huselid MA. Strategic human resources management: where do we go from here? J Manage. 2006;32(6):898-925.

53. Obeidat B, Al-Sarayrah S, Tarhini A, Al-Dmour RH, Al-Salti Z, Sweis R. Cultural influence on strategic human resource management practices: a jordanian case study. Int Bus Res. 2016;9(10):94. doi:10.5539/ibr.v9n10p94

54. Combs JG, Liu Y, Hall A, Ketchen D. How much do high-performance work practices matter? A meta-analysis of their effects on organizational performance. Pers Psychol. 2006;59:501-528. doi:10.1111/j.1744-6570.2006.00045.x

55. Birdi K, Clegg C, Patterson M, et al. The impact of human resource and operational management practices on company productivity: A longitudinal study. Pers Psychol. 2008;61(3):467-501. doi:10.1111/j.1744-6570.2008.00136.x

56. Searle R, Den Hartog DN, Weibel A, et al. Erratum to trust in the employer: the role of high-involvement work practices and procedural justice in European organizations. Int J Hum Resour Manag. 2011;22(5):1069-1092. Int J Hum Resour Manag. 2011; 22 (8):1823. doi:10.1080/09585192.2011.556782

57. Wright PM, Nishii LH. Strategic HRM and organizational behavior: integrating multiple levels of analysis. CAHRS Work Pap Ser. 2007;468. Available from: https://digitalcommons.ilr.cornell.edu/ cgi/viewcontent.cgi?referer=https://scholar.google.com.pk/ \&httpsredir $=1 \&$ article $=1469 \&$ context $=$ cahrswp. Accessed May 17, 2019.
58. Donate MJ, Guadamillas F. An empirical study on the relationships between knowledge management, knowledge-oriented human resource practices and innovation. Knowl Manag Res Pract. 2015;13(2):134-148. doi:10.1057/kmrp.2013.36

59. Posthuma RA, Campion MC, Masimova M, Campion MA. A high performance work practices taxonomy. J Manage. 2013;39 (5):1184-1220.

60. Kaufman BE. A theory of the firm's demand for HRM practices. Int J Hum Resour Manag. 2010;21(5):615-636. doi:10.1080/ 09585191003658797

61. Gardner TM, Wright PM, Moynihan LM. The impact of motivation, empowerment, and skill-enhancing practices on aggregate voluntary turnover: the mediating effect of collective affective commitment. Pers Psychol. 2011;64(2):315-350. doi:10.1111/ j.1744-6570.2011.01212.x

62. Naz S. Effect of HR practices on employee wellbeing: A case of telecom sector of Pakistan. Inter $J$ of Manag Res and Eme Sci. 2011;1(1):37-59.

63. Wayne S, Shore L, Liden R. Perceived organizational support and leader-member exchange: A social exchange perspective. Acad Manag J. 1997;40(1):82-111.

64. Ghoshal S, Bartlett CA. Linking organizational context and managerial action: the dimensions of quality of management. Strateg Manag J. 1994;15(2 S):91-112. doi:10.1002/smj.4250151007

65. Robinson SL, Kraatz MS, Rousseau DM. Changing obligations and the psychological contract: A longitudinal study. Acad Manag J. 1994;37(1):137-152.

66. Pfeffer J. The human equation: building profits by putting people first. Acad Manag Perspect. 1998;12:93-95.

67. Cheung MFY, Law MCC. Relationships of organizational justice and organizational identification: the mediating effects of perceived organizational support in Hong Kong. Asia Pacific Bus Rev. 2008;14 (2):213-231. doi:10.1080/13602380701430879

68. Chew YT, Wong SK. Effects of career mentoring experience and perceived organizational support on employee commitment and intentions to leave: a study among hotel workers in Malaysia. Int J Manag. 2008;25(3):692-779.

69. Burnett MF, Chiaburu DS, Shapiro DL, Li N. Revisiting how and when perceived organizational support enhances taking charge. $J$ Manage. 2015;41(7):1805-1826.

70. Muse LA, Stamper CL. Perceived organizational support: evidence for a mediated association with work performance. $J$ Manag Issues. 2007;19(4):517-535-459.

71. Cobb S. Social support as a moderator of life stress. Psychosom Med. 1976;38(5):300-314.

72. Shore LM, Wayne SJ. Commitment and employee behavior: comparison of affective commitment and continuance commitment with perceived organizational support. J Appl Psychol. 1993;78 (5):774-780.

73. Greenberg MS. A theory of indebtedness. In: Social Exchange. Boston, MA: Springer Publishers US; 1980:3-26.

74. Blau H. Power and exchange in social life. New York: John Wiley \& Sons; 1964.

75. DeConinck JB. The effect of organizational justice, perceived organizational support, and perceived supervisor support on marketing employees' level of trust. J Bus Res. 2010;63(12):13491355. doi:10.1016/j.jbusres.2010.01.003

76. Kurtessis JN, Eisenberger R, Ford MT, Buffardi LC, Stewart KA, Adis CS. Perceived organizational support: a meta-analytic evaluation of organizational support theory. J Manage. 2017;43(6):18541884.

77. Eisenberger R, Cummings J, Armeli S, Lynch P. Perceived organizational support, discretionary treatment, and job satisfaction. $J$ Appl Psychol. 1997;82(5):812-820. 
78. Guzzo RA, Noonan KA. Human resource practices as communications and the psychological contract. Hum Resour Manage. 1994;33(3):447-462. doi:10.1002/(ISSN)1099-050X

79. Jung HS, Yoon HH. The effects of emotional intelligence on counterproductive work behaviors and organizational citizen behaviors among food and beverage employees in a deluxe hotel. Int $J$ Hosp Manag. 2012;31(2):369-378. doi:10.1016/j.ijhm.2011. 06.008

80. Kalleberg AL. Work values and job rewards: a theory of job satisfaction. Am Sociol Rev. 1977;42(1):124. doi:10.2307/ 2117735

81. Mercer D. Job satisfaction and the secondary headteacher: the creation of a model of job satisfaction. Sch Leadersh Manag. 1997;17(1):57-68. doi:10.1080/13632439770168

82. Wright TA, Cropanzano R. Well-being, satisfaction and job performance: another look at the happy/productive worker thesis. Acad Manag Proc. 1997;1997(1):364-368. doi:10.5465/ambpp.1997. 4988986

83. Wong CS, Hui C, Law KS. A longitudinal study of the job perception-job satisfaction relationship: A test of the three alternative specifications. J Occup Organ Psychol. 1998;71(2):127146. doi:10.1111/j.2044-8325.1998.tb00667.x

84. Vanden Berghe J. Job satisfaction and job performance at the work place [doctoral thesis]. Helsinki: Arcada University of Applied Sciences Ltd.; 2011;1-51.

85. Wu P-C, Chaturvedi S. The role of procedural justice and power distance in the relationship between high performance work systems and employee attitudes: A multilevel perspective. J Manage. 2009;35(5):1228-1247.

86. Gould-Williams J. The effects of "High Commitment" HRM practices on employee attitude: the views of public sector workers. Public Adm. 2004;82(1):63-81. doi:10.1111/j.0033-3298.2004.00383.x

87. Den Hartog DN, Boselie P, Paauwe J. Performance Management: a Model and Research Agenda. Applied psychology. 2004;53(4), 556-569.

88. Delery JE, Shaw JD. The strategic management of people in work organizations: review, synthesis, and extension. Res Pers Hum Resour Manag. 2001;20:165-197.

89. Becker BE, Huselid MA, Pickus PS, Spratt MF. HR as a source of shareholder value: research and recommendations. Hum Resour Manage. 1997;36(1):39-47. doi:10.1002/(ISSN)1099-050X

90. Ghoreishi FS, Zahirrodine AR, Assarian F, Moosavi SGA, Zare Zadeh Mehrizi M. Evaluation of emotional intelligence and job satisfaction in employees of kashan hospitals. Nurs midwifery Stud. 2014;3(1):e11977. doi:10.17795/nmsjournal11977

91. Falkenburg K, Schyns B. Work satisfaction, organizational commitment and withdrawal behaviours. Manag Res News. 2007;30 (10):708-723. doi:10.1108/01409170710823430

92. Judge TA, Bono JE, Thoresen CJ, Patton GK. The job satisfactionjob performance relationship: A qualitative and quantitative review. Psychol Bull. 2001;127(3):376-402.

93. Dinoka G, Perera N, Khatibi A, Navaratna N, Chinna K. Job satisfaction and job performance among factory employees in apparel sector. Asian J Manag Sci Educ. 2014;3(1):96-104.

94. Velnampy T. Job attitude and employees performance of public sector organizations in Jaffna District, Sri Lanka. GITAM J Manag. 2008;6(2):66-73.

95. Petty MM, McGee GW, Cavender JW. A meta-analysis of the relationships between individual job satisfaction and individual performance. Acad Manag Rev. 1984;9(4):712-721. doi:10.5465/ amr.1984.4277608

96. Iaffaldano MT, Muchinsky PM. Job satisfaction and job performance: A meta-analysis. Psychol Bull. 1985;97:251-273. doi:10.1037/0033-2909.97.2.251
97. Caldwell DF, O'Reilly CA. Measuring person-job fit with a profilecomparison process. J Appl Psychol. 1990;75(6):648-657. doi:10.1037/0021-9010.75.6.648

98. Paauwe J, Richardson R. Introduction. Int J Hum Resour Manag. 1997;8(3):257-262. doi:10.1080/095851997341621

99. Guest D. Human resource management, corporate performance and employee wellbeing: building the worker into hrm. J Ind Relations. 2002;44(3):335-358. doi:10.1111/1472-9296.00053

100. Bakker AB, Albrecht SL, Leiter MP. Key questions regarding work engagement. Eur J Work Organ Psychol. 2011;20(1):4-28. doi:10.1080/1359432X.2010.485352

101. Cooke FL, Cooper B, Bartram T, Wang J, Mei H. Mapping the relationships between high-performance work systems, employee resilience and engagement: a study of the banking industry in China. Int J Hum Resour Manag. 2016;1-22. doi:10.1080/ 09585192.2015.1137618

102. Jenkins S, Delbridge R. Context matters: examining "soft" and "hard" approaches to employee engagement in two workplaces. Int J Hum Resour Manag. 2013;24(14):2670-2691. doi:10.1080/ 09585192.2013.770780

103. Kahn WA. Psychological conditions of personal engagement and disengagement at work. Acad Manag J. 1990;33(4):692-724.

104. Macey WH, Schneider B. The meaning of employee engagement. Ind Organ Psychol. 2008;1(1):3-30. doi:10.1111/j.17549434.2007.0002.x

105. Schaufeli WB, Salanova M, Gon Alez-Ro VA, Bakker AB. The measurement of engagement and burnout: a two sample confirmatory factor analytic approach. J Happiness Stud. 2002;3:71-92. doi:10.1023/A:1015630930326

106. Teh $P$, Sun H. Knowledge sharing, job attitudes and organisational citizenship behaviour. Ind Manag Data Syst. 2012;112(1):64-82. doi:10.1108/02635571211193644

107. Stanton P, Nankervis A. Linking strategic HRM, performance management and organizational effectiveness: perceptions of managers in Singapore. Asia Pacific Bus Rev. 2011;17(1):67-84. doi:10.1080/13602381003790382

108. Stanton P, Pham HT. Managing employee performance in an emerging economy: perceptions of Vietnamese managers. Asia Pacific Bus Rev. 2014;20(2):269-285. doi:10.1080/13602381.2013.825975

109. Albrecht SL, Bakker AB, Gruman JA, Macey WH, Saks AM. Employee engagement, human resource management practices and competitive advantage. J Organ Eff People Perform. 2015;2 (1):7-35.

110. Rich BL, Lepine JA, Crawford ER. Job engagement: antecedents and effects on job performance. Acad Manag J. 2010;53(3):617635. doi: 10.5465 /amj.2010.51468988

111. Ashforth BE, Humphrey RH. Ashforth \& Humhrey, 1995.pdf. Hum Relations. 1995;48(2):97-125. doi:10.1177/001872679504800201

112. Baumruk R. Why managers are crucial to increasing engagement: identifying steps managers can take to engage their workforce. Strateg HR Rev. 2006;5(2):24-27. doi:10.1108/14754390680000863

113. Miles RH. Beyond the age of Dilbert: accelerating corporate transformations by rapidly engaging all employees. Organ Dyn. 2001;29(4):313-321. doi:10.1016/S0090-2616(01)00036-5

114. Singh M, James PS. Antecedents and consequence of work engagement: A literature review. Int $J$ Appl Bus Econ Res. 2016;14(12):8635-8656.

115. Schaufeli WB, Bakker AB. Job demands, job resources, and their relationship with burnout and engagement: A multi-sample study. $J$ Organ Behav. 2004;25(3):293-315. doi:10.1002/job.248

116. Bakker AB, Schaufeli WB, Leiter MP, Taris TW. Work engagement: an emerging concept in occupational health psychology. Work Stress. 2008;22(3):187-200. doi:10.1080/0267837080 2393649 
117. Bakker AB, Heuven E. Emotional dissonance, burnout, and in-role performance among nurses and police officers. Int J Stress Manag. 2006;13(4):423-440. doi:10.1037/1072-5245.13.4.423

118. Bakker AB, Demerouti E. Towards a model of work engagement. Career Dev Int. 2008;13(3):209-223. doi:10.1108/13620430 810870476

119. van Knippenberg D. Work motivation and performance: a social identity perspective. Appl Psychol An Int Rev. 2000;49(3):357. doi:10.1111/1464-0597.00020

120. Karatepe OM. High-performance work practices and hotel employee performance: the mediation of work engagement. Int $J \quad$ Hosp Manag. 2013;32:132-140. doi:10.1016/j.ijhm. 2012.05.003

121. Boselie P, Dietz G, Boon C. Commonalities and contradictions in HRM and performance research. Hum Resour Manag J. 2005;15 (3):67-94. doi:10.1111/j.1748-8583.2005.tb00154.x

122. Wright P, Purcell J, Boxall P. The Oxford Handbook of Human Resource Management. Oxford University Press Inc., New york ; 2008.

123. Tregaskis O, Daniels K, Glover L, Butler P, Meyer M. High performance work practices and firm performance: a longitudinal case study. Br J Manag. 2013;24(2):225-244. doi:10.1111/j.14678551.2011.00800.x

124. Zhang Y, Duysters G, Cloodt M. The role of entrepreneurship education as a predictor of university students' entrepreneurial intention. Int Entrep Manag J. 2014;10(3):623-641. doi:10.1007/ s11365-012-0246-z

125. Shore LM, Tetrick LE, Shore TH, Barksdale K. Construct validity of measures of becker's side bet theory. J Vocat Behav. 2000;57 (3):428-444. doi:10.1006/jvbe.1999.1749

126. Moorman RH, Blakely GL, Niehoff BP. Does perceived organizational support mediate the relationship between procedural justice and organizational citizenship behavior? Acad Manag J. 1998;41 (3):351-357. doi:10.5465/256913

127. Saks AM, Rotman JL. Antecedents and consequences of employee engagement. J Manag Psychol. 2006;21(7):600-619. doi:10.1108/ 02683940610690169
128. Cropanzano R, Mitchell MS. Social exchange theory : an interdisciplinary review social exchange theory : an interdisciplinary review. J Manage. 2005;31(6):874-900.

129. Mason M. Sample size and saturation in $\mathrm{PhD}$ studies using qualitative interviews. Forum Qual Soc Res. 2010;11:3.

130. Hakanen JJ, Bakker AB, Schaufeli WB. Burnout and work engagement among teachers. J Sch Psychol. 2006;43(6):495-513. doi:10.1016/j.jsp.2005.11.001

131. Janssen O, Van Yperen NW. Employees' goal orientations, the quality of leader-member exchange, and the outcomes of job performance and job satisfaction. Acad Manag J. 2004;47 (3):368-384.

132. Hair JF, Ringle CM, Sarstedt M. PLS-SEM: indeed a Silver Bullet. J Mark Theory Pract. 2011;19(2):139-152. doi:10.2753/ MTP1069-6679190202

133. Henseler J, Ringle CM, Sarstedt M. A new criterion for assessing discriminant validity in variance-based structural equation modeling. J Acad Mark Sci. 2015;43(1):115-135. doi:10.1007/s11747014-0403-8

134. TrustB. Effect to the random model A predictive approach. Biometrika. 2013;61(1):101-107.

135. Stone M. Cross-validatory choice and assessment of statistical predictions. J R Stat Soc Ser B. 1974;36:111-147.

136. Saeed R, Mussawar S, Lodhi RN, Iqbal A, Nayab HH, Yaseen S. Factors affecting the performance of employees at work place in the banking sector of Pakistan. academia.edu. 2013;17(9):1200 1208. doi:10.5829/idosi.mejsr.2013.17.09.12256

137. Liu F, Chow IHS, Gong Y, Wang H. Mediating links between HRM bundle and individual innovative behavior. $J$ Manag Organ. 2016;25(1)157-172.

138. Du Y, Zhang L, Tekleab AG. Job strains, job control, and POS on employee performance: an interactionist perspective. J Bus Res. 2018;82:213-219. doi:10.1016/j.jbusres.2017.09.040

139. García-Chas R, Neira-Fontela E, Varela-Neira C. High-performance work systems and job satisfaction: a multilevel model. $J$ Manag Psychol. 2016;31(2):451-466. doi:10.1108/JMP-04-20130127 


\section{Supplementary materials}

Table SI Questionnaire

\begin{tabular}{|c|c|c|c|c|c|c|}
\hline \multirow[t]{2}{*}{ Sr No. } & \multirow[t]{2}{*}{ Statements } & \multicolumn{5}{|c|}{ Scale } \\
\hline & & $\begin{array}{l}\text { I } \\
\text { SDA }\end{array}$ & $\begin{array}{l}2 \\
\text { DA }\end{array}$ & $\begin{array}{l}3 \\
\mathbf{N}\end{array}$ & $\begin{array}{l}4 \\
A\end{array}$ & $\begin{array}{l}5 \\
\text { SA }\end{array}$ \\
\hline
\end{tabular}

(a) High performance work system

To what extent your professional staff...

\begin{tabular}{l|l} 
I. & Are hired after employment tests (e.g. skills tests)
\end{tabular}

2. Hold jobs which are designed after formal job analysis to identify position requirements (such as

required knowledge, skills or abilities)

3. Hold non-entry level jobs which have been filled as a result of internal promotions (as opposed to hired from outside of the organization)

4. Receive formal individual performance appraisals

5. Receive formal performance appraisals from more than one source (i.e., from several individuals such as supervisors, peers etc.

6. Have access to company incentive plans, profit-sharing plans, and/or gain-sharing plans

7. Receive their performance appraisals which are used to determine their compensation

8. Receive their performance appraisals which are used to set goals and plan skill development

9. Receive above market wage levels to attract and retain them

10. Are included in a formal information sharing programme (e.g., a newsletter)

II. Are asked to complete attitude surveys on a regular basis

12. Participate in Quality of Work Life (QWL) programs, Quality Circles (QC), and/or labour-management participation teams

13. Have access to a formal grievance procedure and/or complaint resolution system

14. Receive continuous training, e.g. continuous professional development

15. Receive mentoring through articles, and case studies

16. Are organized in self-directed work teams in performing a major part of their work roles

(b) Job Satisfaction

\begin{tabular}{l|l}
\hline I. & In general, I like my job. \\
2. & All in all, I'm satisfied with my job. \\
3. & In general, I like working here.
\end{tabular}

(c) Perceived Organizational Support

\begin{tabular}{|l|l|l|l|l|l|}
\hline I. & The organization values my contribution to its well-being. & & & & \\
2. & The organization appreciate any extra effort from me. & & & & \\
3. & The organization would not ignore any complaint from me. & & \\
4. & The organization really cares about my well-being. & & \\
5. & Even if I did the best job possible, the organization would notice. & & \\
6. & The organization cares about my general satisfaction at work. & & \\
7. & The organization shows concern for me. & & \\
8. & The organization takes pride in my accomplishments at work. & & & \\
\hline
\end{tabular}

(d) Employee performance

\begin{tabular}{|l|l|l|l|l|}
\hline I. & I always complete the duties specified in my job description & & & \\
2. & I meet all the formal performance requirements of the job. & & & \\
3. & I fulfill all responsibilities required by my job. & & & \\
4. & I never neglect aspects of the job that my is obligated to perform. & & & \\
5. & I am often able to perform essential duties & & & \\
\hline
\end{tabular}

(Continued) 
Table SI (Continued).

\begin{tabular}{|c|c|c|c|c|c|c|}
\hline \multirow[t]{2}{*}{ Sr No. } & \multirow[t]{2}{*}{ Statements } & \multicolumn{5}{|l|}{ Scale } \\
\hline & & $\begin{array}{l}\text { I } \\
\text { SDA }\end{array}$ & $\begin{array}{l}2 \\
\text { DA }\end{array}$ & $\begin{array}{l}\mathbf{3} \\
\mathbf{N}\end{array}$ & $\begin{array}{l}4 \\
A\end{array}$ & $\begin{array}{l}5 \\
\text { SA }\end{array}$ \\
\hline \multicolumn{7}{|c|}{ (e) Employee engagement } \\
\hline I. & At my work, I feel bursting with energy & & & & & \\
\hline 2. & At my job, I feel strong and vigorous & & & & & \\
\hline 3. & I am enthusiastic about my job & & & & & \\
\hline 4. & My job inspires me & & & & & \\
\hline 5. & When I get up in the morning, I feel like going to work & & & & & \\
\hline 6. & I feel happy when I am working intensely & & & & & \\
\hline 7. & I am proud of the work that I do & & & & & \\
\hline 8. & I am immersed in my work & & & & & \\
\hline 9. & I get carried away when I am working & & & & & \\
\hline
\end{tabular}

Abbreviations: Sr, serial number; SDA, strongly disagree; DA, disagree; $N$, neutral; A, agree.

\section{Publish your work in this journal}

Psychology Research and Behavior Management is an international, peer-reviewed, open access journal focusing on the science of psychology and its application in behavior management to develop improved outcomes in the clinical, educational, sports and business arenas. Specific topics covered in the journal include: Neuroscience, memory and decision making; Behavior modification and management; Clinical applications; Business and sports performance management; Social and developmental studies; Animal studies. The manuscript management system is completely online and includes a very quick and fair peer-review system, which is all easy to use. Visit http://www. dovepress.com/testimonials.php to read real quotes from published authors. 